\title{
Gender Stereotyping of Political Candidates
}

\author{
An Experimental Study of Political Communication
}

\author{
Toril Aalberg \& Anders Todal Jenssen
}

\begin{abstract}
Electoral research has demonstrated how men and women sometimes have different political preferences. Men are typically thought to be more concerned about taxation, business policies, etc., while women care more about issues related to the welfare state. Thus, it seems obvious that stereotyping influences candidate evaluation with regard to issue competence. In this article, we investigate whether stereotyping also influences how the electorate views the communication skills of the candidates. We ask whether the gender of politicians affects the way citizens evaluate various aspects of the qualities of a political speech, and thus their support for political parties. The experiment used in this study is based on a pre- and post-stimuli questionnaire. Stimuli are videotapes of genuine political speeches (originally given by party leaders in October 2000) performed for the experiment by one female and one male actor. Our main finding is that the male "politician" was believed to be more knowledgeable, trustworthy and convincing than the female "politician" even though they presented the same speech verbatim. These differences in scores were the result of the male part of the audience consistently rating the female lower and the male higher than did the females in the audience. Among the female audience, the two politicians received almost identical scores on all traits. The candidate's popularity and the popularity of the candidate's party were also affected by the gender of the politician who performed the speech.
\end{abstract}

Key Words: political communication, gender, stereotypes, experiments, election campaigns, female candidates

\section{Introduction}

In most modern democracies, equality between men and women has become the dominant ideal within the mainstream political discourse. Men and women should naturally have the same rights, and no one should be excluded from political life. Nevertheless, there are substantial differences both between countries and between different political spheres as to how much and what kind of equality exists. There are several reasons why some countries or some policy areas are more gender equal then others, and everything from regime and institutional features to elements of culture have been used to explain why politics is generally still dominated by male politicians. 
Norway is one of the countries in which gender equality has ranked high on the political agenda. Helga Hernes (1987) even coined the phrase "state feminism" to describe the ambition among the Norwegian political elite to foster gender equality by means of state intervention. With minor variations, this has been the policy of every Norwegian government during the past 25 years. In the political sphere, this has led to a remarkable increase in the political participation and representation of women in politics. Female voters and young women considering a political career have had plenty of female role models in significant positions such as prime minister, minister of defense, minister of the interior, party leader, etc. during recent decades. However, the top-down process resulted in a remarkable pattern of female representation: The ratio of women to men decreased as you moved down the ladder from cabinet members to members of parliament, from parliament to members of regional and municipal councils, and finally from the local councils to party members. This has gradually shifted to a situation in which $40 \%$ of both cabinet ministers and party members are women. This "feminization" of Norwegian politics led Matland (1994) to hypothesize that gender stereotypes have ceased to be important in Norwegian electoral politics.

In 2001, the percentage of female cabinet misters was 42.2, and only Sweden ranked higher in terms of gender equal cabinets. In comparison, 16.7 percent of cabinet members were women in the United States (Katz \& Koole 2002, 887-888). Hence, the Norwegian case offers a critical test for analyzing whether politics is still a male sphere (even in a country in which female politicians have played a major and important role for decades). In this article, we wish to investigate whether stereotyping influences how the electorate views the communication skills of political candidates. And if it does will the popularity of the candidate and the candidate's party be influenced as well? More specifically we ask whether a male and a female politician presenting the same speech are evaluated similarly in terms of their communicative strengths. If not, does this different evaluation influence support for the political party? The analysis is based on experiments run prior to the 2001 Norwegian general election. We used a pre- and post-stimuli questionnaire, and the videotaped stimuli consisted of genuine political speeches (originally given by Norwegian party leaders in October 2000). For the experiment, these speeches were performed by one female and one male actor acting as backbenchers from the various parties. The videos were presented to a sample of first-time voters, where some randomly selected groups watched the female labor candidate, while other groups watched the male labor candidate or the female conservative candidate, etc. In other words, each participant only saw one videotaped speech.

\section{Gender-issue Approach}

Until the early 1980s, the average female voter was considered more religious and conservative than her male counterpart. The parties on the left and especially the far left were more popular among male than female voters. Female politicians were scarce and often considered curiosities or simply ignored. The traditional voting pattern was reversed in several countries in the early 80 s, which led to a renewed interest in what became known as the "gender gap": the increased propensity of women to vote for parties on the left (cf. Mueller (ed.) 1988, Listhaug, Huseby \& Matland 1995). In the 80s, men were typically described as more conservative, whereas women were more liberal or oriented towards the political left. Eventually, researchers also focused on the careers of the growing number of female politicians. One line of research has pointed to how traditional views on gen- 
der roles among voters might work against female candidates by influencing how voters perceive candidate traits, beliefs and issue positions (Sapiro 1982, Rosenwasser \& Seale 1988, Leeper 1991, Huddy \& Terkilsen 1993, Alexander \& Andersen 1993, Kahn 1994, Matland 1994, Koch 2000, King \& Matland 1999, Sanbonmatsu 2002). Experimental studies have shown that female candidates were affiliated with certain "female themes", whereas men were considered more knowledgeable on "male issues" - when the assessments were based on identical political messages (Sapiro 1982, Matland 1994). Other studies demonstrated how female candidates were viewed more positively if the political campaign evolved around typical "female issues" (Kahn 1996), and how male and female candidates developed different campaign strategies. While men tended to concentrate on economic issues, women seemed much more likely to discuss social issues (Kahn 1993). Traditional gender stereotypes were believed to "fill in the blanks" whenever voters lacked information, either because no information was provided or because the information was ignored or forgotten. When asked, respondents made up their minds on the basis of a mixture of relevant knowledge and stereotypes. The less knowledgeable respondents were, the more likely it was that traditional stereotypes would come into play. Others have however found the exact opposite pattern. Koch (2002) finds that those with the highest levels of knowledge are most likely to use stereotypes.

That candidates of different gender are perceived to have different competence areas is not necessarily negative for the popularity of the candidates and their parties. Women might stand for different policies and thus bring new issues into politics, consequently attracting new or less mobilized groups of voters. The idea is that female politicians open new dimensions of party competition by emphasizing new issues. We might label this the gender-issue approach. Female politicians may also introduce new dimensions of personal competence into politics. Their "newness" does not mean that these personal traits are insignificant. If gender stereotypes do influence voters' perceptions of issue salience and issue positions, this might in turn influence other significant perceptions as well, such as the candidate's ability to communicate, bring compassion into politics, and her capacity to persuade important sections of the electorate, etc. If female politicians are attributed different personal skills, this might also have an impact on their popularity and the popularity of the parties they represent. These questions have become more important as voters seem to be more volatile and change party preference from one election to the next. Moreover, an increasing share of voters now decide which party they will vote for during the election campaign. Hence, how the party and their candidates are able to communicate and, thus, mobilize the electorate has become increasingly important.

\section{Gender Stereotyping of Candidates and Gender Favoritism}

Whether we like to admit it or not, we all use stereotypes as information shortcuts in everyday life. Because we cannot have full information about everything, we often rely on conventional and oversimplified conceptions. Hence, voters may use candidate gender as an "information shortcut" to estimate the features of a politician, as they might use other demographic characteristics or partisanship to evaluate political candidates (Popkin 1991). But whereas partisanship is often a relevant characteristic to judge political candidates by, gender stereotypes might be misleading and have a negative impact on the process of getting more women involved in politics.

In a society with a traditional division of labor, gender stereotypes tend to be strong, that is, they are shared by both men and women and have a profound effect on attitudes 
and behavior. Assessments of role performance will be based on a different set of expectations for male and female politicians. Any politician trying to cross the line between the realm of male and female politicians will stand out as misplaced and risk becoming a laughing stock among both women and men. In a country in which females have served as prime minister, minister of defense, minister of transportation, minister of the interior, just to mention a few positions, traditional views on the role of female politicians have been profoundly challenged. Today it seems more relevant to ask whether women and men judge the same performance by a female and male politician by the same standards.

Markus et al. (1982) used the term "gender schema" to refer to an individual's shelf schema about gender identity rather than social beliefs about gender. But it was Bem (1981) who first introduced the gender schema theory. She emphasized that there is a link between individuals' gender schema and their own gender identity. Fiske and Taylor (1991) argued that schemas organize information and facilitate information processing, or in other words: gender schemas store information about gender categories in our memory. Others have pointed to how these schemas refer to our "intuitive hypotheses about the behavior, traits and preferences of men and women" (Valian 1998, 11). Applied to politics, gender schemas mean that voters have intuitive hypotheses about the behavior, traits and preferences of male and female politicians based on their gender (Sanbonmatsu 2002). Assuming that most people recognize, identify with and understand their own gender, it seems likely that many voters will have a preference for politicians of their own gender, take an interest in their issues and identify with their style of communication.

To analyze gender stereotypes, scholars commonly use a between-subjects experimental design. Participants in the experiment are normally asked to evaluate a single candidate based on biographical information or a short speech, and the stimuli are the same across all subjects, except that one candidate is male and the other is female. These studies have demonstrated that people do evaluate performance differently and solely on the basis of the candidate's gender. Some issues, such as crime, defense and foreign policy issues, are typically perceived to be handled better by men, whereas women are more able to deal with social and feminist issues. These stereotypes may come from stereotypes about men and women in general or knowledge of the behavior of men and women in politics. Scholars, however, have not reached a consensus on whether gender stereotypes affect voting behavior, although a few studies suggest that gender stereotypes do indirectly influence vote choice (Kahn 1996, McDermott 1997, Dolan 1998, Sanbonmatsu 2002). Female representatives are often perceived to be more liberal than they actually are. As gender schema theory suggests, voters also tend to have preferences for one gender over the other - based on stereotypes related to issue competence and personal traits. Matland suggested that the gender bias may not necessarily harm the chances of female candidates, as it merely reflects that women are perceived to have different areas of expertise, not that these areas are less important. "The crucial assumption is that while voters perceive differences in competence, these do not disadvantage women, because women's areas of expertise are valued as highly as men's areas of expertise" (Matland 1994, 288).

This different-but-equal explanation may work when considering gendered difference in issue competence, but other factors are important to succeeding in politics. Sapiro (1982), Alexander and Andersen (1993), Huddy and Terkildsen (1993) and Matland (1994) offered additional insight into a few questions on more personal competence. Huddy and Terkildsen concluded that male "characteristics" such as toughness, decisive- 
ness, etc., were preferred over female characteristics, suggesting that there are negative implications of gender stereotypes for female politicians. Although Matland did not find any significant difference in how candidates of different gender were evaluated on candidate traits $(1994,286)$, he did find that conservative voters perceived the male politician as better able to argue for the party's policies. This was not the case for Labor supporters. Are men perceived to be better communicators or was this a random feature appearing only among conservative voters?

\section{Gender Bias, Political Communication and Election Campaigns}

Matland's finding of a gender bias in relation to the candidate's ability to argue for the party's policies is interesting, particularly if one considers how electoral campaigns have changed during the past few decades. A growing body of studies have stressed how candidate characteristics influence the vote in the US and Great Britain. Thus far, in other countries with multiparty PR systems, individual candidates have not been regarded as particularly important. In these countries, the effect of personal characteristics on the vote has not been considered significant (Aardal \& Narud 2003). Still, political commentators, journalists and the political candidates themselves seem to believe that the personal characteristics of the candidates as well as their media appeal is becoming more and more important for the vote, also in countries with a party-oriented electoral system (Jenssen \& Aalberg 2006). The media are partly blamed for this new trend, and the concept of personification or presidentialization of European politics is up-and-coming (Mughan 2000, King ed. 2002). Voters are less loyal to the parties, and a large share of the electorate decide whom they will vote for just a few days prior to Election Day. Thus, they are more open to short-term factors such as popular candidates. As much of the campaign takes place in the media, it is vital for politicians to be able to communicate the party's policy in the best possible way.

The parties themselves seem to have caught on to this trend, and most national-level politicians are now being trained to perform in the media and particularly on television. Within the parties, this is seen as a response to the fact that the party will only receive media attention if it makes use of media competent politicians. Even if there will not be the same kind of "gendered political races" in PR systems as there are in majoritarian systems, personal traits including communication skills and media appeal seem to be important in the nominating process within parties. The parties need their profiled leaders to get across to the voters via the media, and research suggests that popular candidates and party leaders gain more general support for their party than do candidates who are less charismatic (Jenssen \& Aalberg 2004).

Feminist scholars have stressed the media's role in the so-called "antithesis relationship of women and politics" (Sreberny \& van Zoonen 2000). As core intermediaries in contemporary democracies, the media are deeply implicated in the process of defining and framing gender. They represent and reconstruct the contrast between femininity and politics, both in the popular culture and in serious political reporting. Women are underrepresented in the political sphere, but even more so in the media coverage. Women have a harder time gaining access to and being portrayed in the media (Gjørven, Grønn \& Vaagland 2000), and when they do receive coverage, reporters often ask more personal and apolitical questions (van Zoonen 2000, Eide 2000). The journalists admit that they use fewer female than male sources, partly due to the way in which men and women communicate. Whereas men are perceived to be more direct and confrontational 
in their style, the journalists feel that women use more words and are cagier than men. This reasoning can be seen as a continuance of the gender stereotype hypothesis. Studying Norwegian political TV debates, however, Krogstad (1999) found that female politicians were as aggressive as male politicians. Kahn and Gordon's study (1997) also demonstrates that, although women and men seem to present alternative agendas to voters, with regard to which issues they emphasize, they deliver these distinct messages in a remarkably similar fashion.

\section{Experimental Design}

In an attempt to show how gender stereotypes may affect the perceived communication skills of political candidates, we conducted a set of experiments connected to the largest parties prior to the 2001 Norwegian national election. In this study, we wished to isolate the effect of the gender of the candidate who presents the political message as well as to hold all other factors (including party) constant.

We wished to include the five largest parties in Norwegian politics, as well as to choose a speech that was as identical as possible for the various parties. In other words, it was important that the candidate talk about issues that were of general importance to the party, as well as that the length of the speech be as similar as possible. Therefore, we chose to use recordings from the "Address Debate" held at the opening of the Norwegian parliament in the fall of 2000. ${ }^{1}$ The length of the recordings varied from 12 to 17 minutes. It is important to note that these speeches were not direct appeals to the voters. Neither content nor presentation can be described as particularly charismatic.

The manuscripts from the 5 speeches were given to an actor and an actress who were told to perform the speeches in the same manner as the leaders had performed them. Only a few minor changes in the manuscript were made, and just to eliminate the leaders' direct references to personal actions or personal quotes. ${ }^{2}$ After having studied the recordings of the party leaders to imitate their form, the actor and actress presented the same speech verbatim. The actor and actress were digitally edited onto the Storting podium, resulting in high picture quality. The camera angle was the same as for the original Norwegian Broadcasting Company's (NRK) recordings of the leaders. The cuts to the audience, etc., in the hall were also edited in, so that the final videotapes of the simulated "backbenchers" were identical to those of the party leaders. Reverberation was also added to the recordings of the "backbenchers", and the NRK logo and hypertext were identical for the original recordings and the constructed ones. We constructed names for the backbenchers from Statistics Norway's (SSB) list over most used names. None of the 409 subjects who saw the recordings of the actor or actress expressed any doubts about the authenticity of the videotape. It is the research group's firm belief that the actor's and actress's presentations of the message are not significantly different from those of the leaders with regard to important factors such as involvement, voice production, body language, speed, etc. The rather dreary original speeches did not give the actors much room for lively interpretation. For a visual illustration of the stimuli, see Figure 1.

The subjects in the experiment consisted of first-time voters recruited through the comprehensive schools in 4 different municipalities. We visited all final year classes in these municipalities, and although this is not a representative sample, the group gives a good insight into first-time voters within the geographical area, ${ }^{3}$ simply because a majority of the population is included. Seventy-three percent were born in 1983 and 




Male "Backbencher"

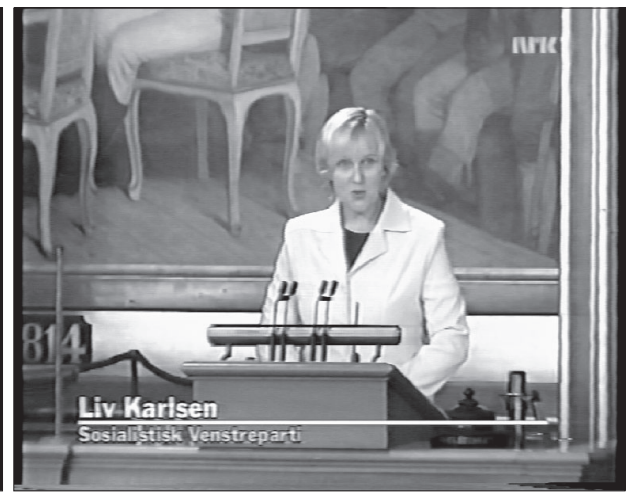

Female "Backbencher"

turned 18 in 2001. Compared to the general population, our sample had a larger share (20\%) of supporters for the Socialistic Left Party (which is typical of Norwegian firsttime voters). Women were also slightly overrepresented in our sample (58 percent, as opposed to 42 percent men). We aimed at getting an equal distribution of subjects across the various forms of stimuli.

It was primarily practical concerns that led us to use a sample of first-time voters. As always when dealing with non-representative samples, one should reflect over whether or not this influences the analytical results. It is a well-known fact that first-time voters are less politically active, have less political experience and are less knowledgeable about politics compared to the population in general. Therefore, first-time voters are also considered to be more easily influenced by new information, as they lack the objections older voters have often acquired. This suggests that first-time voters would be particularly sensitive to any stimuli and that we would be able to achieve stronger effects in our sample, if these effects do indeed exist. However, it is important to bear in mind that our experiments aim at capturing the potential effects of already established opinions. There is reason to believe that many first-time voters not only lack firm opinions on central political issues, but that they also lack established opinions about party politics in general. A total of 53 percent of the subjects in the experiments said that they had little or no interest in politics.

The experiments were conducted during one school lesson (45 minutes). Pupils were told that they could choose not to participate, but that they were not allowed to leave the classroom. Only a very small number of pupils, all with a non-Norwegian background, exchange students, etc., chose not to participate in the experiment. The subjects answered a short questionnaire before watching the taped speech. After exposure, the subjects were given a new questionnaire.

\section{Analysis}

Let us first turn to the question of whether gender influences the perception of candidates' communication skills. Measuring each respondent's reaction to the speech gave rise to several concerns. First, we wished to direct the audience's focus toward the speech as such and not toward the messenger. Second, our intention was that the characterizations should 
be as distinct and recognizable as possible to a broad audience. Third, we wished to elicit both positive and negative statements. Finally, we wished to facilitate a focus on qualities of political communication frequently discussed in the literature.

We ended up with a battery of eight questions designed to tap important features of a good political speech. The subjects were asked: "We would like to know your opinion on different features of the speech you just saw. How much do you agree or disagree with the following statements? Please place a mark on a scale from 0 to 10 , where 0 means that you disagree completely and 10 means that you completely agree with the statement." The statements were: "The speech communicated knowledge", "The speech was boring", "The speech was trustworthy", "The speech was irrelevant", "The speech was convincing", "The speech was inspiring", "The speech was alarming and worrying", "The speech was optimistic and hopeful".

The classical rhetorical distinction between convincing by means of logic and ethos (that is making the ethical status of the speaker an argument itself) is represented by the two traits "knowledge" and "trustworthy". Pathos, the rhetorical style directed toward arousing emotions in the audience, is represented by "optimistic and hopeful" and "alarming and worrying". These two items can also be linked to George Marcus's (Marcus 1988; 1991) work on the emotional underpinnings of political campaigns. The traits "inspiring" and "boring" can be related to the concept 'charismatic speech' (and the lack thereof), whereas "convincing" and "irrelevant" are more sweeping characterizations, expressing general approval and outright dismissal.

Comparisons of means on these scales are presented in Table 1 for those who saw a male candidate and those who saw a female candidate. The overall pattern is clear. The male candidate was perceived as performing better then the female candidate. On six out of eight features, the score for the male candidate is higher, and for the only two statements did the female candidate achieve a higher score; the difference between the groups is not significant. Both statements reflect negative aspects, such as the speech being boring and irrelevant. The data suggest, however, that the speech seemed significantly more knowledgeable, trustworthy and convincing when the male candidate presented it than when the female candidate did.

Table 1. Candidate Gender in Relation to Political Speech Traits

\begin{tabular}{lcccc} 
Speech traits & Female Candidate & Male Candidate & T-test & Probability \\
\hline Knowledgeable & 4.41 & $5.26^{* \star}$ & -3.46 & 0.00 \\
Trustworthy & 4.55 & $5.08^{* *}$ & -2.30 & 0.02 \\
Convincing & 3.87 & $4.39^{\star *}$ & -2.00 & 0.05 \\
Inspiring & 3.36 & 3.59 & -0.83 & 0.41 \\
Optimistic and hopeful & 3.50 & 3.82 & -1.27 & 0.20 \\
Alarming and worrying & 3.48 & 3.33 & 0.56 & 0.57 \\
Boring & 5.78 & 6.03 & -0.84 & 0.40 \\
Irrelevant & 3.34 & 3.16 & 0.72 & 0.48 \\
Smallest N & 152 & 257 & & \\
\hline
\end{tabular}

**Significant at the 0.05 level, 2-tailed test

Gender schema would suggest that there might be a difference in how men and women evaluate candidates of the same gender. The typical hypothesis is that voters may favor candidates of their own gender, such that men evaluate the male candidate as better, 
whereas women rank the female candidate higher than the male candidate. In order to explore this assumption, we ran separate analyses for men and women. The findings, which are presented in Table 2, are quite striking. There is no clear support for an overall gender solidarity hypothesis. There are generally small and insignificant differences in how women evaluate male and female candidates, suggesting that gender seems to be unimportant to women. Turning to men's scores of the candidates, the story is quite different. Men rate the candidate significantly more favorably on most features when the candidate is male. The only two statements on which men rate the female candidate higher are the two clearly negative traits. Although far from significant, the men in our sample perceived the speech to be somewhat more boring and more irrelevant when it was performed by the female candidate.

Table 2. Candidate Gender in Relation to Political Speech Traits as Rated by Male and Female Respondents

\begin{tabular}{|c|c|c|c|c|c|c|c|c|}
\hline \multirow[b]{2}{*}{ Speech traits } & \multicolumn{4}{|c|}{ Male respondents } & \multicolumn{4}{|c|}{ Female respondents } \\
\hline & $\begin{array}{l}\text { Female } \\
\text { Candidate }\end{array}$ & $\begin{array}{c}\text { Male } \\
\text { Candidate }\end{array}$ & T-test & Prob. & $\begin{array}{c}\text { Female } \\
\text { Candidate }\end{array}$ & $\begin{array}{c}\text { Male } \\
\text { Candidate }\end{array}$ & T-test & Prob. \\
\hline Knowledgeable & 4.12 & $5.78^{* *}$ & -4.28 & 0.00 & 4.59 & 4.89 & -0.95 & 0.34 \\
\hline Trustworthy & 4.34 & $5.36^{* *}$ & -2.59 & 0.01 & 4.68 & 4.88 & -0.71 & 0.48 \\
\hline Convincing & 3.62 & $4.79^{* *}$ & -2.85 & 0.01 & 4.02 & 4.09 & -0.20 & 0.84 \\
\hline Inspiring & 2.90 & 4.02 ** & -2.57 & 0.01 & 3.65 & 3.26 & 1.15 & 0.25 \\
\hline $\begin{array}{l}\text { Optimistic } \\
\text { and hopeful }\end{array}$ & 3.29 & 4.09 * & -1.93 & 0.06 & 3.63 & 3.62 & 0.04 & 0.97 \\
\hline $\begin{array}{l}\text { Alarming } \\
\text { and worrying }\end{array}$ & 3.33 & 3.61 & -0.65 & 0.52 & 3.57 & 3.12 & 1.41 & 0.16 \\
\hline Boring & 5.92 & 5.89. & 0.04 & 0.97 & 5.69 & 6.13 & -1.18 & 0.24 \\
\hline Irrelevant & 3.26 & 3.13 & 0.30 & 0.76 & 3.39 & 3.19 & 0.66 & 0.51 \\
\hline Smallest $\mathrm{N}$ & 58 & 109 & & & 94 & 147 & & \\
\hline
\end{tabular}

Note: Entries are means on a scale ranging from 0 to 10 .**Significant at the 0.05 level, 2 -tailed test * Significant at the 0.10 level, 2-tailed test.

Thus far, we have looked at simple bivariate relationships. The question remains whether these significant differences will hold when we run a multivariate analysis involving all these factors as well as controlling for which political party the subjects were exposed to. The first multivariate analysis is presented in Table 3 and shows how the political speech was evaluated. A political speech index was created including 4 of the more positive dimensions: knowledge, trustworthiness, being convincing and inspiring. The three OLS regressions confirm that the significant relationship between candidate gender and communication skills remains even after controlling for other factors. Model 1 provides a first control for our stimuli variable when sex of respondent and the respondents' political interest are controlled for. Model 2 demonstrates that the effect of the gender manipulated stimuli remains even after controlling for the political party represented in the stimuli. The reference category consists of those who were exposed to a Christian People's Party speech. We see that Model 2 reveals a significant negative effect of having been exposed to a candidate representing the Progress Party. The negative effect is likely to have been caused by our sample being somewhat biased against this party. This does not mean that our sample deviates from the population, on the contrary. No other party is so strongly disliked by the majority and at the same time loved by its followers than is the right wing Progress Party. 
Table 3. Regression: Political Speech Index

\begin{tabular}{lcccccc} 
& \multicolumn{2}{c}{ Model 1 } & \multicolumn{2}{c}{ Model 2 } & \multicolumn{2}{c}{ Model 3 } \\
\hline & B & beta & B & beta & B & beta \\
Constant & $15.92^{* *}$ & & $15.31^{* *}$ & & $16.55^{* *}$ & \\
Gender stimuli & $1.85^{* *}$ & .11 & $1.98^{* *}$ & .11 & & \\
Sex of respondent & -1.10 & -.07 & -1.08 & -.06 & & \\
Male gender identification & & & & & $3.55^{* *}$ & .19 \\
Female gender identification & & & & & 0.71 & .04 \\
Political interest & -0.48 & -.03 & 0.18 & .01 & 0.09 & .01 \\
Stimuli party: SV & & & 1.78 & .09 & $2.27^{*}$ & .12 \\
Stimuli party: AP & & & -0.87 & -.04 & -0.23 & -.01 \\
Stimuli party: H & & & -1.92 & -.10 & -1.85 & -.09 \\
Stimuli party: FrP & & & $-2.31^{*}$ & -.11 & -1.73 & -.08 \\
$\mathrm{R}^{2}$ & & .02 & & .05 & & .07 \\
$\mathrm{~N}$ & & 415 & & 415 & & 415 \\
\hline
\end{tabular}

Note: Entries are OLS regression coefficients. **Significant at the 0.05 level, *Significant at the 0.10 level. Dependent variable: political speech index, consisting of following traits: knowledge, trustworthy, convincing and inspiring. Chronback's Alpa $=0.88$, bivariate correlations range between 0.59 and 0.75 . Values of independent variables are: Sex of respondent, $0=$ men, $1=$ women, Male gender identification, $1=$ men exposed to male candidate, $0=$ everybody else. Female gender identification, $1=$ women exposed to female candidate, $0=$ everybody else. Political interest $1=$ low interest, $2=$ high interest. Stimuli party $1=$ seen party, $0=$ everybody else. Christian People's Party is left out as the reference group.

Model 3 runs the same control, but in this model we have investigated a possible interaction effect between stimuli and the sex of the respondents. Recall from the theoretical discussion earlier that the gender schema theory suggests that gender identity favoritism may occur, such that men would favor the male candidate and women would favor the female candidate. The bivariate analysis in Table 2 suggests that such gender identity favoritism only applies to men. This is confirmed in Model 3 in Table 3. We see that men who saw the male candidate were much more likely to view the speech as more knowledgeable, trustworthy, convincing and inspiring, resulting in a significant standardized beta coefficient of .19. Women who were exposed to the female candidate still regarded the speech somewhat more positively than others, but the relationship is weak and insignificant. Model 3 seems to explain somewhat more of the variance, resulting in an $\mathrm{R}^{2}$ of .07 compared to .05 for Model $2 .{ }^{4}$

Thus far, our data have shown how the perception of political candidates' communication skills is influenced by gender stereotypes and that the use of stereotypes or gender schema seems to be more activated among men than women. The next question we shall address is whether candidate gender also influences the popularity of the candidate and the party the candidate represents. Two questions were designed to tap candidate and party popularity: (i) "We would like to know how much you liked or disliked the candidate that presented the party message. Can you rank him/her on a scale from 0 to 10 , where 0 indicates that you strongly dislike the candidate and 10 indicates that you like the candidate very much?" and (ii) "We would like to know how much you like or dislike this political party. Can you rank the party on a scale from 0 to 10 , where 0 indicates that you strongly dislike the party and 10 indicates that you like the party very much?" Findings are presented in Table 4. Let us first look at the results for the total sample. We find significant effects indicating that both the candidate and the party were 
given a higher popularity score when the male candidate presented the political message, compared to when the same speech were performed by the female candidate. Table 4. Candidate Gender in Relation to Political Party and Candidate Popularity/
Rating

\begin{tabular}{|c|c|c|c|c|}
\hline Popularity & $\begin{array}{c}\text { Female } \\
\text { Candidate }\end{array}$ & $\begin{array}{c}\text { Male } \\
\text { Candidate }\end{array}$ & T-test & Probability \\
\hline \multicolumn{5}{|l|}{ Total sample } \\
\hline Party & 4.25 & $4.88^{\star *}$ & -2.33 & 0.02 \\
\hline Candidate & 4.32 & $4.66^{*}$ & -1.66 & 0.10 \\
\hline Smallest $\mathrm{N}$ & 152 & 255 & & \\
\hline \multicolumn{5}{|c|}{ Male respondents } \\
\hline Party & 4.09 & 4.75 & -1.51 & 0.13 \\
\hline Candidate & 4.21 & 4.76 & -1.60 & 0.11 \\
\hline Smallest $\mathrm{N}$ & 57 & 112 & & \\
\hline \multicolumn{5}{|c|}{ Female respondents } \\
\hline Party & 4.34 & $4.99^{*}$ & -1.84 & 0.07 \\
\hline Candidate & 4.39 & 4.59 & -0.78 & 0.44 \\
\hline Smallest $\mathrm{N}$ & 95 & 143 & & \\
\hline \multicolumn{5}{|c|}{ Supporters of stimuli party } \\
\hline Party & 7.05 & 7.04 & 0.03 & 0.98 \\
\hline Candidate & 5.77 & 5.39 & 1.08 & 0.28 \\
\hline Smallest N & 39 & 98 & & \\
\hline \multicolumn{5}{|c|}{ Opponents of stimuli party } \\
\hline Party & 3.12 & 3.32 & -0.74 & 0.46 \\
\hline Candidate & 3.64 & $4.10^{*}$ & -1.78 & 0.08 \\
\hline Smallest $\mathrm{N}$ & 95 & 132 & & \\
\hline \multicolumn{5}{|c|}{ High political interest } \\
\hline Party & 4.10 & $4.96^{*}$ & -1.78 & 0.08 \\
\hline Candidate & 3.83 & $4.82^{* *}$ & -3.01 & 0.00 \\
\hline Smallest $\mathrm{N}$ & 72 & 97 & & \\
\hline \multicolumn{5}{|c|}{ Low political interest } \\
\hline Party & 4.38 & 4.84 & -1.45 & 0.15 \\
\hline Candidate & 4.76 & 4.56 & 0.77 & 0.44 \\
\hline Smallest N & 80 & 158 & & \\
\hline
\end{tabular}

Note: Entries are means on a scale ranging from 0 to 10 . **Significant at the 0.05 level, *Significant at the 0.10 level. Supporters of parties represented in the stimuli are respondents who in the pre-stimuli questionnaire gave the party a score of 6 or higher on a scale ranging from 0 to 10. Opponents of the party are respondents who in the pre-stimuli questionnaire gave the party a score of 5 or lower on the same scale. Respondents with high political interest indicated in the pre-stimuli questionnaire that they were very or somewhat interested in politics. Respondents with low political interest indicated in the pre-stimuli questionnaire that they had little or no interest in politics.

Both men and women rated the party or the candidate higher if the male candidate performed the speech. However, the only candidate difference that reaches statistical significance is when women are asked to rate the party the candidate represented. That this difference fails to reach statistical significance among men is probably due to the lower number of male respondents. We see from the means that the difference in rating of the two candidates is larger among men than among women. If we look at supporters and opponents of the party separately, there is hardly any significant difference in candidate 
or party rating based on candidate gender. The only significant difference that occurs is that opponents of the party like the candidate better when the candidate is male than when the candidate is female. Although it fails to reach statistical significance, an interesting pattern emerges. The supporters of the party are actually more positive to the woman than they are to the male candidate. So within a party being female does not hurt, it is among the opponents of the party the true cost lie.

Finally, there seems to be quite an interesting difference between respondents who report a high level of political interest and those who are less politically interested. Whereas the subjects with little political interest do not seem to differentiate a great deal between candidates of different gender, those with high levels of political interest do seem to distinguish between the male and the female candidate. Most apparent is the difference in the candidate popularity rating. The average popularity score when the candidate was female was 3.82, but when the candidate was male the score was 4.82 . The party is also viewed much more favorably if the male candidate performs the speech, although the difference in party popularly scores is smaller than the difference in candidate popularity scores. That those with the highest levels of knowledge are most likely to use stereotypes is consistent with Koch's (2002) findings.

If we turn to the multivariate analysis of the candidate's popularity rating, the story is much the same. The effect of our stimuli variable reaches significance and increases somewhat when we control for the party the subjects were exposed to. However, the effect is not as strong as for the speech evaluations. Moreover, the gender identification variables fail to reach statistical significance. We also see that some of the party controls do have significant effects, suggesting that our left-biased sample gave more positive evaluations when they were exposed to the Socialistic Left Party or the Labor Party. Again, rankings were more negative if the party represented in the stimuli was the Progress Party.

Table 5. Regression: Candidate Popularity

\begin{tabular}{|c|c|c|c|c|c|c|}
\hline & \multicolumn{2}{|c|}{ Model 1} & \multicolumn{2}{|c|}{ Model 2} & \multicolumn{2}{|c|}{ Model 3} \\
\hline & $\mathrm{B}$ & beta & B & beta & $\mathrm{B}$ & beta \\
\hline Constant & $4.36^{\star *}$ & & 4.00 ** & & $4.46^{* *}$ & \\
\hline Gender stimuli & 0.32 & .08 & $0.34^{*}$ & $.08^{*}$ & & \\
\hline Sex of respondent & -0.08 & -.02 & -0.04 & -.01 & & \\
\hline Male gender identification & & & & & 0.34 & .08 \\
\hline Female gender identification & & & & & -0.03 & -.01 \\
\hline Political interest & -0.21 & -.05 & -0.06 & -.02 & -.0 .10 & -.03 \\
\hline Stimuli party: SV & & & $0.58^{*}$ & .13 & $0.62 *$ & .14 \\
\hline Stimuli party: AP & & & 0.52 & .10 & $0.59^{*}$ & .11 \\
\hline Stimuli party: H & & & -0.12 & -.02 & -0.11 & -.02 \\
\hline Stimuli party: FrP & & & $-0.64^{*}$ & -.13 & $-0.56^{*}$ & -.11 \\
\hline $\mathrm{R}^{2}$ & & .01 & & .06 & & .06 \\
\hline $\mathrm{N}$ & & 406 & & 406 & & 406 \\
\hline
\end{tabular}

Note: Entries are OLS regression coefficients. **Significant at the 0.05 level, 2 -tailed test. Dependent variable: popularity rating of candidate on a scale ranging from 0 to 10 . Values of independent variables are: Sex of respondent, $0=$ men, $1=$ women, Male gender identification, $1=$ men exposed to male candidate, $0=$ everybody else. Female gender identification, $1=$ women exposed to female candidate, $0=$ everybody else. Political interest $1=$ low interest, $2=$ high interest. Stimuli party $1=$ seen party, $0=$ everybody else. Christian People's Party is left out as the reference group. 
Table 6 presents a similar analysis of party popularity ratings. The effect of the candidate gender stimuli suggests that the male candidate makes the party somewhat more popular, and this effect remains if we control for party exposure, as in Model 2. As was the case for the candidate popularity ratings, the gender identification variables do not have a significant effect on the party popularity ratings.

Table 6. Regression: Party Popularity

\begin{tabular}{|c|c|c|c|c|c|c|}
\hline & \multicolumn{2}{|c|}{ Model 1} & \multicolumn{2}{|c|}{ Model 2} & \multicolumn{2}{|c|}{ Model 3} \\
\hline & $\mathrm{B}$ & beta & $\mathrm{B}$ & beta & $\mathrm{B}$ & beta \\
\hline Constant & 3.44 & & 2.66 & & $3.18^{* *}$ & \\
\hline Gender stimuli & $0.65^{* *}$ & .12 & $0.58^{* *}$ & .11 & & \\
\hline Sex of respondent & 0.24 & .05 & 0.24 & .04 & & \\
\hline Male gender identification & & & & & 0.22 & .04 \\
\hline Female gender identification & & & & & -0.11 & -.02 \\
\hline Political interest & 0.00 & .00 & 0.18 & .03 & 0.07 & .01 \\
\hline Stimuli party: SV & & & $1.47^{* *}$ & .24 & $1.51^{* *}$ & .25 \\
\hline Stimuli party: AP & & & $1.72^{* *}$ & .46 & $1.81^{* *}$ & .25 \\
\hline Stimuli party: $\mathrm{H}$ & & & -0.02 & -.00 & -0.03 & -.01 \\
\hline Stimuli party: FrP & & & -0.07 & -.01 & 0.05 & .01 \\
\hline $\mathrm{R}^{2}$ & & .02 & & .10 & & .08 \\
\hline $\mathrm{N}$ & & 410 & & 410 & & 410 \\
\hline
\end{tabular}

Note: Entries are OLS regression coefficients. **Significant at the 0.05 level, 2 -tailed test. Dependent variable: popularity rating of party on a scale ranging from 0 to 10 . Values of independent variables are: Sex of respondent, $0=$ men, $1=$ women, Male gender identification, $1=$ men exposed to male candidate, $0=$ everybody else. Female gender identification, $1=$ women exposed to female candidate, $0=$ everybody else. Political interest $1=$ low interest, $2=$ high interest. Stimuli party $1=$ seen party, $0=$ everybody else. Christian People's Party is left out as the reference group.

\section{Discussion}

How are we to account for the "gender blindness" found among women compared to the gender favoritism found among males? Over the past two decades, the gender gap has proven to be particularly significant among young voters. Young females are the backbone of the Socialist Left Party, whereas young males have flocked to the Progress Party. The Progress Party stresses traditional family values and strongly opposes any "discrimination of men". Traditional gender stereotypes still have followers, and some of them are young males.

Perhaps the most obvious explanation for women's "gender blindness" is that many women still reason like underdogs: The idea that a female politician can be as good as a male politician is radical, believing that female politicians may even be better is seen as extremism. On the other hand, if this interpretation has any merit, it is more likely to explain attitudes among older women than among the young women in our sample. We must also remind ourselves that our respondents did not make a direct comparison; they gave their views on the basis of a single performance. Turning the underdog argument on its head, one could claim that young women now take gender equality for granted to the extent that they see gender as irrelevant. In 2001, almost every major party had strong, visible women within their leadership. These female politicians did quite well in the TV_debates during the 2001 campaign and soon became media darlings. More- 
over, the memory of the strong premiership of Gro Harlem Bruntland was still vivid. In short, nothing indicated to them that gender might still make a difference in politics; they were raised under "state feminism".

We have not yet discussed our implicit assumption that our male and female actors did an equally good job of presenting the various speeches. What if this assumption is invalid? Although actors have become both president and governor, it is hard to believe that all actors and actresses have the talents required for this particular role. If the male actor's impersonation of a politician was in fact better - displaying the traits we associate with capable politicians - the results among female viewers may be explained by gender favoritism, i.e. that the female "politician" scored relatively well among female viewers, in spite of her less convincing performance. We have no way of falsifying this partly methodological explanation of our findings. This illustrates a general problem with experimental methods and underscores the need for replicating similar experiments. However, if this methodological explanation is correct, it does not invalidate the gender favoritism hypothesis; on the contrary, it enhances it. If the young female subjects rated the female "backbencher" positively despite her inferior performance, this means that gender favoritism is not confined to the young males.

\section{Conclusion}

Our main finding is that the male "politician" was believed to be more knowledgeable, trustworthy and convincing than the female "politician" even though they presented the same speech verbatim. These differences in scores were the result of the male part of the audience consistently rating the female lower and the male higher than did the females in the audience. Among the female audience, the two politicians received almost identical scores on all traits. The candidate's popularity and the popularity of the candidate's party seem to be affected as well by the gender of the politician who performed the speech. However, the multivariate analysis suggests that these findings are somewhat less robust.

The integration of women into party politics is one of the major changes to have taken place in Norway over recent decades. In many ways, this has been a success story, and indeed, the story has been told often enough. The change has been profound, and politicians using blatant sexist language risk being punished by their parties. ${ }^{5}$ However, everyone has not wholeheartedly accepted these changes. Not surprisingly, the young males in our sample seem to favor male over female politicians, at least when it comes to communication skills. We suspect that this pattern may be even more pronounced among the older generations of males. Their reaction can be interpreted as the result of relative deprivation: Over a few decades, the traditional male dominance in political life has disappeared. The power to define what politics is all about, the traits that make a successful politician, etc., now have to be shared. This has not been altogether easy for men. How do the $98 \%$ male armed forces react to a female Minister of Defense demanding cutbacks? Or how do the $80 \%$ male farmers respond to a female Minster of Agriculture slashing subsidies? We are not altogether surprised to find some resentment and gender favoritism even among young men, despite Norway's 25 years of "state feminism". 


\section{Notes}

1. The following party leaders originally performed the speech: Jens Stoltenberg from Labor (DNA), Jan Pettersen from the Conservatives (H), Kjell Magne Bondevik from the Christians People's Party (KrF), Carl I. Hagen from Progress Party (FrP), and Kristin Halvorsen from the Socialistic Left Party (SV). Kristin Halvorsen was the only female politician.

2. When, for instance, Carl I. Hagen in his speech said "... as I proposed to the Storting in February" this was changed to "... as the Progress Party proposed to the Storting in February".

3. All subjects are not included in this analysis as some saw the original speech performed by the party leader. For a complete description of the dataset, see Brekken, Govasmark, Aalberg \& Jenssen (2003).

4. In 2000, only one of the party leaders was female - and one could argue that it was more difficult for the female actress to interpret the speeches given by male party leaders. We did run separate analyses for the various parties (not shown here), and the female candidate did not do significantly better among those who saw the Socialist Left Party speech (originally performed by the female party leader). The difference between the male and female candidate was, however, especially strong and significant for those who saw the speech given by the Conservative party. This is in accordance with Matland (1994, 286), who found that conservative voters perceive the male politician to be better able to argue for the party's policies. Perhaps expectations about conservative female politicians are different. Several female politicians, and perhaps especially Conservative women, have been described as "iron ladies" and "men in skirts" (Like Margaret Thatcher in the UK and the current Norwegian Conservative leader Erna Solberg, also called Iron Erna).

5. For instance, it has been argued that the popular politician Bjarne Håkon Hansen lost his chance of becoming deputy leader of the Labour Party when he publicly made that remark that "she was unusually pretty for being a feminist".

\section{Literature}

Aardal, Bernt \& Hanne Marthe Narud (2003) 'Er lederen viktigere enn partiet og politikken?' in Bernt Aardal (ed.) Velgere $i$ villrede... En analyse av stortingsvalget 2001. Oslo: N.W.Damm \& Søn

Alexander, Deborah \& Kristi Andersen (1993) 'Gender as a Factor in the Attribution of Leadership Traits', Political Research Quarterly 46: 527-545.

Bem, Sandra Lipsitz (1981) 'Gender Schema Theory: A Cognitive Account of Sex Typing', Psycholoical Review 88: 354-364.

Brekken, Tove, Hege Govasmark, Toril Aalberg \& Anders Todal Jenssen (2003) 'Partiledereffekter ved Stortingsvalget 2001. Prosjektbeskrivelse og kodebok for eksperimenter gjennomført høsten 2001', ISS-Rapport nr 63. Trondheim: Department of Sociology and Political Science, NTNU.

Dolan, Kathleen (1998) 'Voting for Woman in 'The Year of the Woman", American Journal of Political Science 42: 272-293.

Eide, Elisabeth (2000) Narrespeil. Kjønn, sex og medier. Kristiansand: Høyskoleforlaget.

Fiske, Susan T. \& Shelley E. Taylor (1991) Social Cognition. New York: McGraw-Hill.

Gjørven, Julie, Margunn Grønn \& Helle Vaagland (2000) 'Det tapte tiåret. Om kvinnebildet i dagspressen ved inngangen til år 2000', in Elisabeth Eide (ed.) Narrespeil. Kjønn, sex og medier. Kristiansand: Høyskoleforlaget.

Hernes, Helga Maria (1987) Welfare State and Woman Power: Essays in State Feminism. Oslo: Norwegian University Press

Huddy, Leonie \& Nayda Terkildsen (1993) 'Gender Stereotypes and the Perception of Male and Female Candidates', American Journal of Political Science 37: 119-147.

Jenssen, Anders Todal \& Toril Aalberg (2006) 'Party-leader Effects in Norway. A Multi-methods Approach', Electoral Studies 25:

Kahn, Kim Fridkin (1996) The Political Consequences of Being a Woman: How Stereotypes Influence the Conduct and Consequences of Political Campaigns. New York: Columbia University Press

Kahn, Kim Fridkin (1993) 'Gender Differences in Campaign Messages: The Political Advertisements of Men and Women Candidates for U.S. Senate', Political Research Quarterly 46: 481-502.

Kahn, Kim Fridkin \& Ann Gordon (1997) 'How Women Campaign for the U.S. Senate', in Pippa Norris (ed.) Women, Media and Politics. Oxford: Oxford University Press.

Katz, Richard S. \& Ruud Koole (2002) 'Political Data in 2001', European Journal of Political Research. Political Data Yearbook 2001. 41: 885-896

King, Anthony (ed.) (2002) Leaders' Personalities and the Outcome of Democratic Elections. Oxford: Oxford University Press. 
King, David \& Richard E. Matland (1999) 'Partisanship and the Impact of Candidate Gender in Congressional Election: Results of an Experiment', Unpublished manuscript.

Koch, Jeffrey W. (2000) 'Do Citizen Apply Gender Stereotypes to Infer Candidates Ideological Orientation', Journal of Politics 62: 414-429.

Koch, Jeffrey W. (2002) 'Gender Stereotypes and Citizens' Impressions of House Candidates' Ideological Orientation', American Journal of Political Science 46: 453-462.

Krogstad, Anne (1999) Image i politikken. Visuelle og retoriske virkemidler. Oslo: Pax forlag.

Leeper, Mark Stephen (1991) 'The Impact of Prejudice on Female Candidates: An Experimental look at Voter Inference', American Politics Quarterly 19: 248-261.

Listhaug, Ola, Beate Huseby \& Richard E. Matland (1995) 'Valgatferd blant kvinner og menn: 1957-1993', in Nina Cecilie Raaum (ed.) Kjфnn og politikk. Oslo: TANO Forlag, 1995.

Marcus, George E. (1991) 'Emotions and Politics: Hot Cognitions and the Rediscovery of Passion', Social Science Information 32:195-232.

Marcus, George E. (1988) 'The Structure of Emotional Response: 1984 Presidential Candidates', The American Political Science Review, Vol. 82: 737-761.

Matland, Richard E. (1994) 'Putting Scandinavian Equality to the Test: An Experimental Evaluation of Gender Stereotyping of Political Candidates in a Sample of Norwegian Voters', British Journal of Political Science 24: 273-292.

Markus, Hazel, Marie Crane, Stan Bernstein \& Michael Siladi (1982) 'Self-Schemas and Gender', Journal of Personality and Social Psychology 42: 38-50.

McDermott, Monika L. (1997) 'Voting Cues in Low-Information Elections: Candidate Gender as a Social Information Variable in Contemporary United States Elections', American Journal of Political Science 41: 270-283.

Mueller, Carol M. (1988) (ed.) The Politics of the Gender Gap. The Social Construction of Political Influence. Sage, Newbury Park.

Mughan, Anthony (2000) Media and the Presidentialization of Parliamentary Elections. Palgrave: Houndsmills.

Popkin, Samuel L. (1991) The Reasoning Voter: Communication and Persuasion in Presidential Campaigns. Chicago: University of Chicago Press.

Rosenwasser, Shirley M. \& Jana Seale (1988) 'Attitudes Towards a Hypothetical Male or Female Presidential Candidate - A Research Note', Political Psychology 9: 591 - 598.

Sanbonmatsu, Kira (2002) 'Gender Stereotypes and Vote Choice', American Journal of Political Science 46: $20-34$.

Sapiro, Virginia (1982) 'If U.S. Senator Baker Were a Woman: An Experimental Study of Candidate Images', Political Psychology 3: 61-83.

Sreberny, Annabelle \& Liesbet van Zoonen (2000) Gender, Politics and Communication Cresskill: Hampton Press.

Valian, Virginia (1998) Why So Slow? The Advancement of Women Cambridge: MIT Press.

van Zoonen, Liesbet (2000) 'Broken Hearts, Broken Dreams? Politicians and Their Families in Popular Culture', in Annabelle Sreberny \& Liesbet van Zoonen (eds.) Gender, Politics and Communication. Cresskill: Hampton Press.

TORIL AALBERG, Dr Polit., Associate Professor, Department of Sociology and Political Science, NTNU, N-7491 Trondheim, toril.aalberg@ @vt.ntnu.no

ANDERS TODAL JENSSEN, Professor, Department of Sociology and Political Science, NTNU, N-7491 Trondheim, anders.todal.jennssen@svt.ntnu.no 